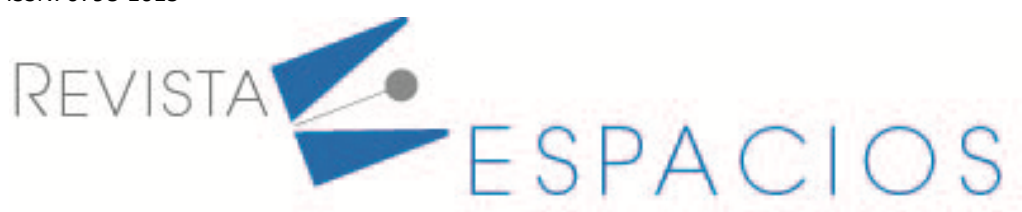

\title{
The clean energy economy: the labour market. Case study: Solar Energy
}

\author{
La economía de las energías limpias: el mercado laboral. Estudio de caso: Energía solar \\ MARTÍNEZ-RODRÍGUEZ, María Concepción ${ }^{1}$ \\ VERA-MARTÍNEZ, Martín C. ${ }^{2}$
}

\begin{abstract}
Conventional energies are directly related to the use of fossil fuels, generating this type of energy entails alarming economic and environmental costs. Based on this, the transition to clean energy, implies modifications in the energy labour market. Specifically, we studied the large labour market that the solar industry can generate in Mexico, with the help of the 3R's methodology, we have adapted it to a circular economy focusing on the solar panels could be the main technology for this sector.

key words: GHG emissions; solar industry; circular economy, labour market

\section{Resumen}

Las energías convencionales están directamente relacionadas con el uso de combustibles fósiles, generar este tipo de energía conlleva unos costos económicos y medioambientales alarmantes. La transición a energías limpias, implica modificaciones en el mercado laboral energético. El objeto que estudiamos es el gran mercado laboral que puede generar la industria solar en México, con la metodología de las 3R adaptada a una economía circular nos enfocamos en los paneles solares que podrían ser la principal tecnología para este sector.

Palabras clave: Emisiones de GEl; industria solar; economía circular, mercado laboral
\end{abstract}

\section{Introduction}

Fossil fuels have long been one of the main sources of energy, a situation that has had an impact on the environment and is currently one of the main causes of climate change (Merino, 2012), as these fuels produce oxides emissions carbon, sulfur and nitrogen (Sardon, 2003).

In 2013, Mexico generated 665.30 million tons of carbon dioxide emissions (CO2), of which 126.61 million tons are from electricity, this is, $19.03 \%$ of total emissions, corresponding to the electricity generation sector (INECCSEMARNAT, 2015).

The problem has become so great that there has been a need to move towards alternative energy sources, or clean energy. These can replace fossil fuel energy sources, do not generate waste and do not pollute, since they use natural resources, such as wind and water.

\footnotetext{
${ }^{1}$ Research professor, Instituto Politécnico Nacional, Centro Interdisciplinario de Investigaciones y Estudios Sobre Medio Ambiente y Desarrollo, México City. México. mcmartinezr@ipn.mx

${ }^{2}$ Research professor, faculty of Economics and International Relations, Autoomous University of Baja California, México.martin.vera@uabc.edu.mx
} 
In recent decades, Mexico has begun to invest in alternative energy, so by the end of 2015, 97 hydroelectric plants, 8 geothermal plants, 32 wind power plants and 9 photovoltaic solar power plants had been established (SENER, 2016a), although in 2016 the greatest energy production still came from oil, natural gas and coal, with $89 \%$ of the total energy produced (SENER, 2017a).

Currently, the Mexican energy sector has around 36,681 workers focused on the Energy Generation and Distribution Industry, of which approximately 7,520 workers are working in the Energy Sustainability Industry within renewable energy generation sources (SENER, 2016b).

\subsection{Justification}

According to the Network of Renewable Energy Policies for the 21st Century, at the end of 2015, 76.3\% of total world electricity production was contributed by non-renewable energy, while $23.7 \%$ was made by renewable energy, such as hydraulic, wind, solar photovoltaic, geothermal and bio-energy energies (REN21, 2016).

In Mexico, of the total energy produced in 2016, 62.6\% comes from oil, $23.1 \%$ from natural gas and 3.3\% from coal, while only $8.4 \%$ corresponds to renewable energy (SENER, 2017a). Mexico is located as a vulnerable country to the effects of climate change due to its geographical location, so it has sought to invest in energies that reduce pollutant emissions and reduce the use of fossil fuels. The states of Oaxaca, Veracruz, Sonora, Chihuahua, and Durango currently stand out in the search for the generation of this type of energy with wind projects, biomass and photovoltaic parks.

Globally, the labour market in this area has benefited in recent years. According to the International Renewable Energy Agency (IRENA) in 2014, there were 7.7 million jobs in the renewable energy sector (IRENA, 2015) and two years later, in 2016, this value increased by reporting 9.8 million jobs in the sector in the world (IRENA, 2017). In this sense, the transition to renewable energies has implied the need to have the assistance of experts in the energy sector, therefore, during this process new jobs have been created and some jobs have been replaced or redefined, this situation requires that governments, through the creation of public policies, help regulate the labour market and generate the tools that provide the necessary conditions to close the skills gaps, reduce labour shortages and do not allow the increase of unemployment in Mexico. Based on this, it is necessary to identify which sectors are vulnerable to restructuring and thus able to provide their workers with an update and training so that they can enter an area where they contribute to the production of clean energy.

\subsection{Objective}

The aim of this research is to show jobs that will be affected in the transition to clean energy by selecting those sectors that contribute to high GHG emissions, for that we also describe the current state of clean energy development in Mexico, we determine if there are areas of opportunities in this sector and finally we intend to visualize the development of the energy labour market in Mexico over the next few years.

\subsection{Theoretical reference}

Since Organization of Petroleum Exporting Countries (OPEC) forced the nations to face the fact that oil and gas would not be cheap and available forever, more attention has been given to alternative energy sources. Among the most attractive is solar energy: clean, free at the source, resistant to monopolistic control and widely available in most regions (Moon, 1981).

The National Development Plan 2013-2018 (PND) and the General Law on Climate Change (LGCC) are part of the regulatory framework in Mexico, regarding climate change. According to Objective 4.4 of the PND, one of the goals to achieve a Prosperous Mexico is to promote green growth, which includes sustainability, environmental care, better water management and natural heritage protection, without neglecting inclusion and employment 
(SEGOB, 2013). What is sought is to include renewable energy sources in technological development, promoting the eradication of dependence on fossil fuels and reducing economic and environmental costs.

According to the Ministry of Energy, in Mexico in 2016, primary energy production was distributed as shown in Figure 1.

Figure 1

Primary energy production, 2016

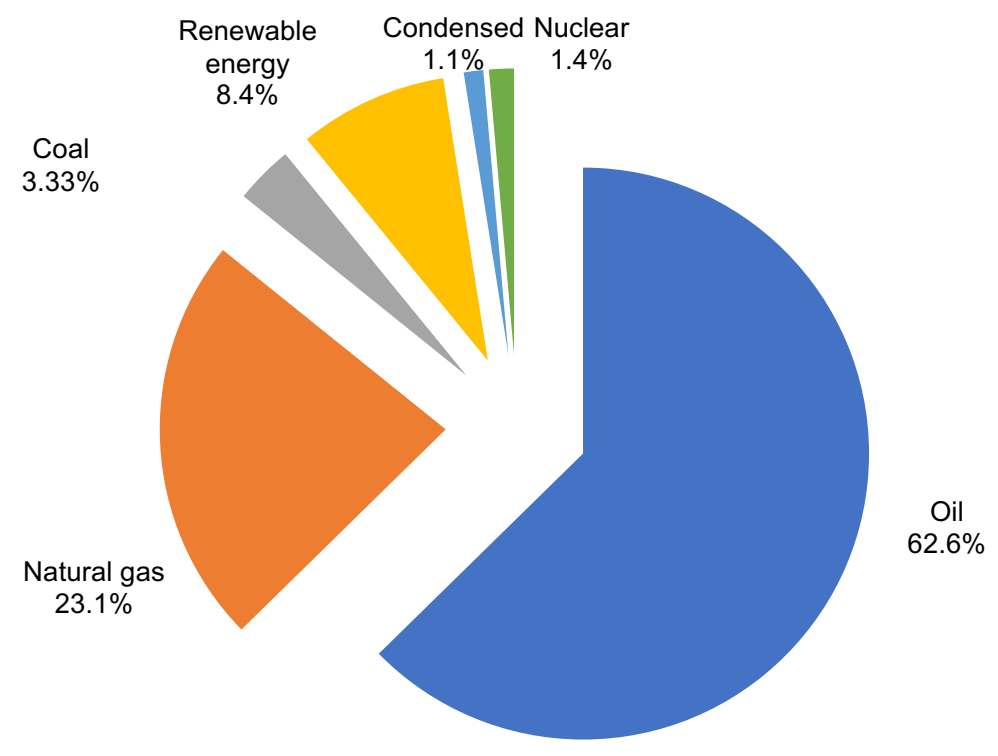

Source: Own elaboration (SENER, 2016a)

It is possible to note that most of the energy produced was obtained through fossil fuels, while only $8.4 \%$ of the energy came from renewable sources. On the other hand, the energy consumption in the country during 2015 corresponds in greater quantity to the Transportation and Industry sectors, as shown in Figure 2.

Figure 2

Distribution of energy consumption by sector

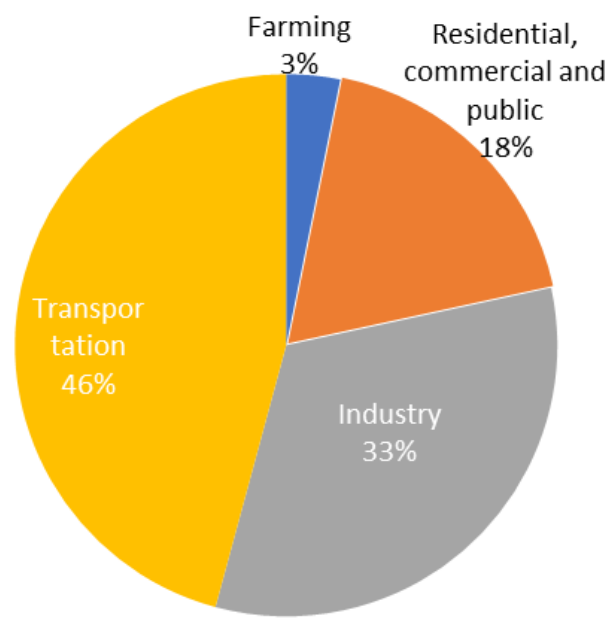

Source: Own elaboration (INECC-SEMARNAT, 2015). 
In this figure, the Transportation sector, which consumes $45.8 \%$ of the energy produced in the country, is a key element in achieving the reduction of GHG emissions. Next is the Industry sector, with an expenditure of $32.6 \%$ of the total, then the Residential, Commercial and Public sector that uses $18.4 \%$, finally the Agricultural sector is located with $3.2 \%$.

Once the energy-consuming sectors have been identified, the areas which pollute the most by generating GHG emissions are determined. Table 1 shows the emissions and polluting participation of each sector in Mexico.

Table 1

GHG emissions in 2013

\begin{tabular}{|c|c|c|}
\hline Sector & $\begin{array}{l}\text { Total GHG [millions of } \\
\text { tons CO2e] }\end{array}$ & Sector Participation [\%] \\
\hline Mobile sources & 174.16 & 26.2 \\
\hline Electricity generation & 126.61 & 19 \\
\hline Residential and commercial & 25.64 & 3.9 \\
\hline Oil and gas & 80.45 & 12.1 \\
\hline Industry & 114.54 & 17.3 \\
\hline Farming & 80.17 & 12 \\
\hline $\begin{array}{l}\text { Waste (urban solid waste, hazardous waste, } \\
\text { wastewater treatment and disposal) }\end{array}$ & 30.90 & 4.6 \\
\hline Land use, land-use change and forestry & 32.42 & 4.9 \\
\hline Total emissions & 665.30 & 100 \\
\hline
\end{tabular}

Source: Own elaboration (INECC-SEMARNAT, 2015)

In the previous table it is noticeable that the most polluting sector is Mobile sources, which is composed of all types of motor vehicles, with a total of 174.17 million tons of GHG, followed by electricity generation, which emits 126.61 million tons of GHG, and later is Industry, which generates 114.54 million tons of GHG. Figure 3 shows the percentage of participation of each polluting sector.

Figure 3

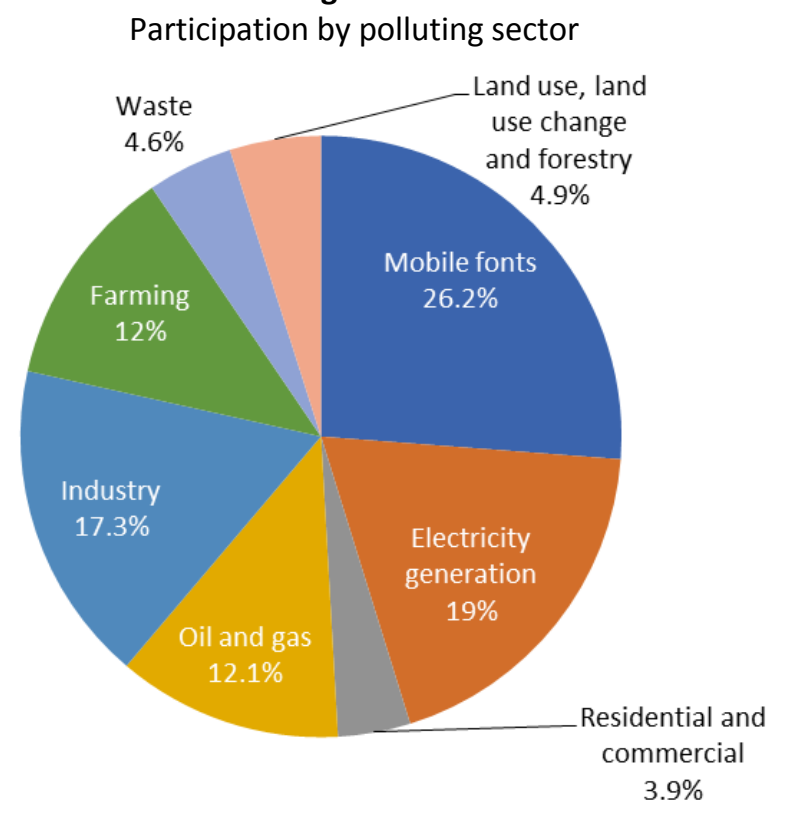

Source: Own elaboration (INECC-SEMARNAT, 2015).

The contribution to total GHG emissions from the Mobile Sources sector is $26.2 \%$, followed by Electricity Generation with $19 \%$ and the Industry sector that contributes $17.3 \%$ of the total GHG emissions in Mexico. Based 
on this information, it is determined that these three sectors are key to significantly reduce pollution in Mexico due to GHG emissions.

With respect to the Electricity generation sector, Figure 4 shows the percentage of participation that different technologies had in the production of electric energy in 2016, within these are conventional technologies such as combined cycle, thermoelectric, turboelectric, turbogas, internal combustion and nuclear power, as well as alternative technologies, such as hydroelectric, wind, geothermal, solar and bioenergy.

Figure 4

Electricity generation by type of technology in 2016

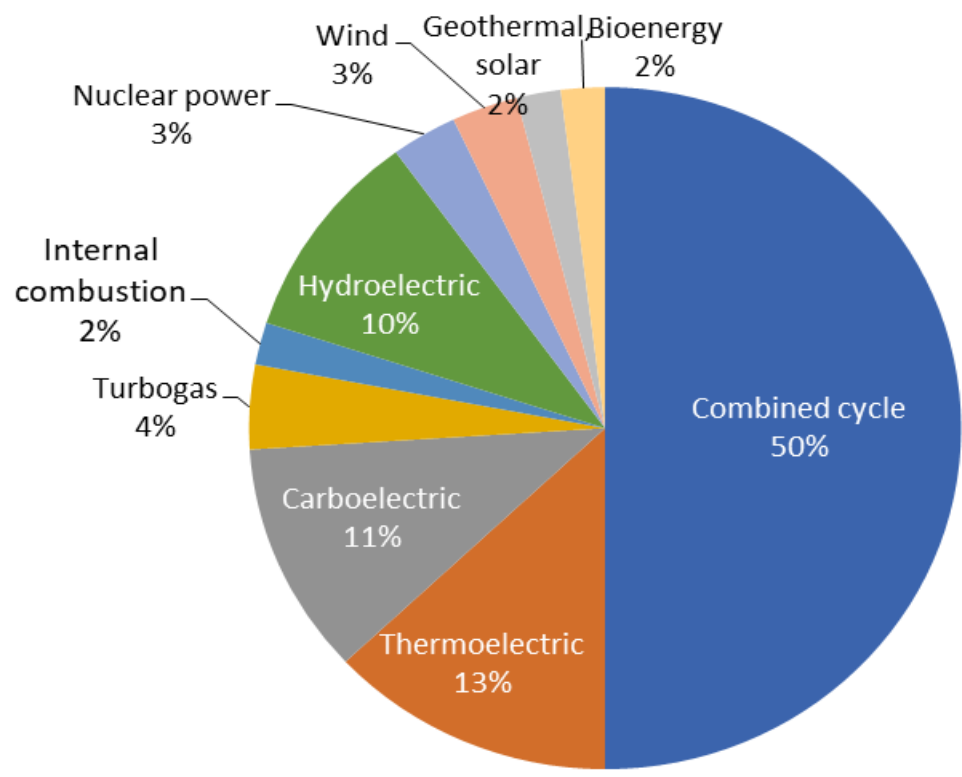

Source: SENER, 2017b

According to the Ministry of Energy, in 2016, most of the electricity generation was obtained through the combined cycle and thermoelectric technologies, with $50 \%$ and $13 \%$ of the total, respectively, while the use of renewable technologies, such as Hydroelectric and Wind, has a lower production, with $10 \%$ and $3 \%$ respectively (SENER, 2017b).

Table 2 shows the GHG emissions produced by non-renewable technologies in the generation of electricity.

Table 2

GHG emissions of the electricity generation sector by technology

\begin{tabular}{lcc}
\hline Technology & Total GHG [millions of tons CO2e] & Participation [\%] \\
\hline Carboelectric (Dual) & 34.87 & 27.55 \\
Internal combustion & 0.94 & 0.74 \\
Thermoelectric & 34.02 & 26.86 \\
Combined cycle & 54.78 & 43.27 \\
Turbogas & 2.0 & 1.58 \\
\hline Total & 126.61 & 100 \\
\hline
\end{tabular}

Source: Own elaboration (INECC-SEMARNAT, 2015).

All these technologies work through fossil fuels, that is, through the combustion of coal, natural gas, fuel oil, oil or coal. According to the previous information, it is understood that there is an urgency to reduce the use of 
carbonized energy and to increase the generation of clean energy. Consequently, this advance in the energy sector also implies that new activities and areas of opportunity arise, as well as a change in the supply and demand of the labour market in the energy sector (SENER, 2016b). On one hand, there will be work areas vulnerable during the transition to clean energy, and, on the other hand, new areas of opportunity will create diverse employment options. Table 3 shows how many people are working in the determined polluting sectors.

Table 3

Population employed in polluting economic activity sectors, quarter IV of 2017

\begin{tabular}{lc}
\hline \multicolumn{1}{c}{ Activity } & $\begin{array}{c}\text { Population [millions } \\
\text { of people] }\end{array}$ \\
\hline Extractive and electricity industry & 0.41 \\
Manufacturing industry & 8.75 \\
Building & 4.36 \\
Transportation, communications, mail, and storage & 2.71 \\
\hline \multicolumn{2}{c}{ Total } \\
\hline
\end{tabular}

Source: Own elaboration (INEGI, 2018)

In the Mobile sources, Electricity generation and Industry sectors, until 2017, 16.23 million people worked, that is, these workers are in the vulnerable areas to be transformed, redefined or eliminated, representing $30.70 \%$ of the Mexican population employed (INEGI, 2018).

In contrast, Table 4 shows a list of the most important key occupations that would form the labour force in the generation of clean energy in Mexico, both for the development phase, as for the operation and maintenance phase; the majority are specialized occupations, although non-specialized occupations are also of significant importance for the sector.

Table 4

Key occupations in the clean electric energy sector Occupation

Assistants and technicians in biological, chemical and environmental sciences

Assistant in social sciences and humanities

Civil and construction engineers

Coordinators and department heads in generation and supply of electricity and water

Directors and managers in generation and provision of electricity and water

Ecologists and specialists in atmospheric sciences

Electrical engineers

Electricians and linemen

Engineers in topography, hydrology, geology and geodesy

Analysts and financial advisors

Geographers

Lawyers

Mechanical engineers

Maintenance and mechanical repair technicians of industrial machinery and instruments

Machinery and plant operators for power generation

Surveyor assistants and hydrology and geology technicians

Source: SENER (2016b)

As can be seen, key occupations require knowledge in engineering and earth sciences, managerial or managerial aspects and technical skills. According to the Ministry of Energy [6], personnel trained in occupations such as agronomist, chemical engineers, communications and telecommunications engineers, carpenters, technicians in 
the installation, repair and maintenance of refrigeration equipment, climates and air conditioning are also required, industrial designers and occupational safety and hygiene technicians.

Based on the Talent Perspective Report, Volume 6 (SENER, 2016b), by 2020, there will be an expected offer of 8,216 workers for the renewable energy production sector. The states with the highest labour supply are shown in Figure 5.

Figure 5

States with the highest labour supply in 2020

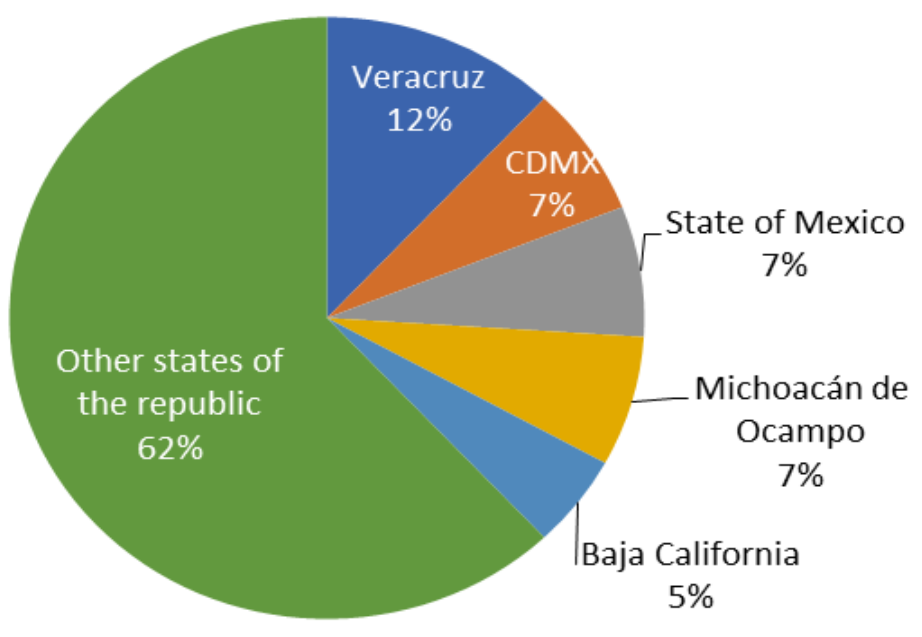

Source: Own elaboration (SENER, 2016b)

On the other hand, Figure 6 shows the states of the republic that have a greater number of clean power generation plants, that is, hydroelectric, wind, geothermal, solar or bioenergy plants.

Figure 6

States with more power plants for clean energy

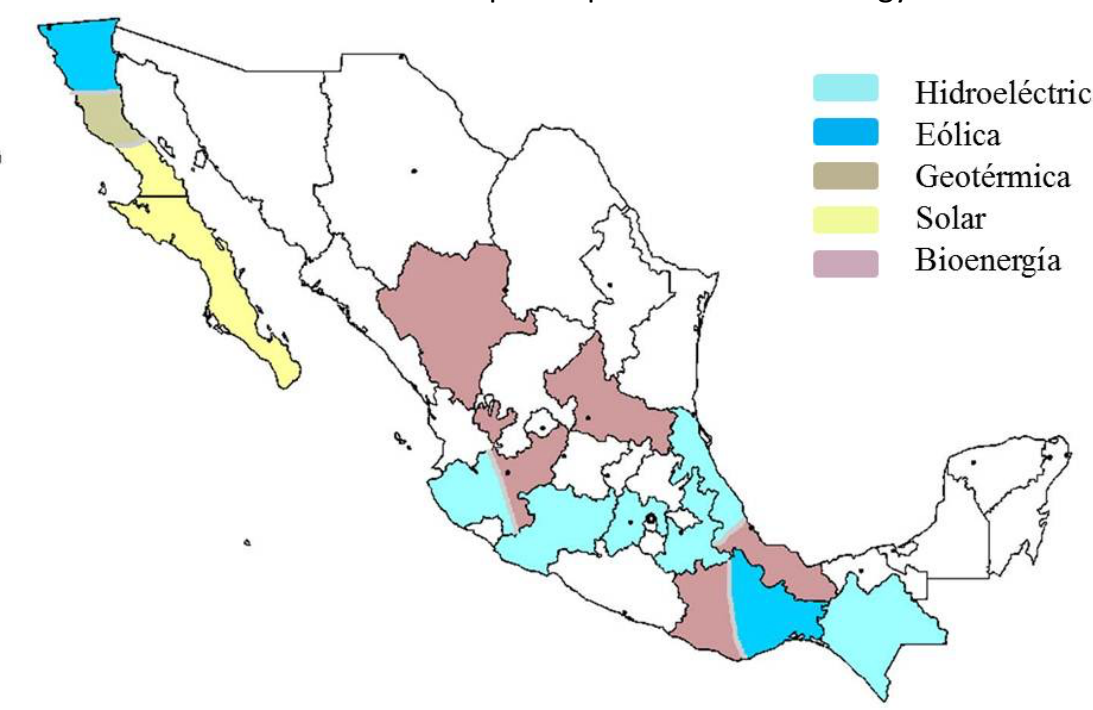

Source: Own elaboration (SENER, 2016a)

In comparison, it is appreciated that states such as Veracruz, Mexico City, State of Mexico and Michoacán de Ocampo will have a great supply of labour, while it is the states of Veracruz, Baja California, Jalisco and Oaxaca 
where the largest will be required number of workers This means that supply and demand are not consistent, since there will be locations where labour will be needed and, conversely, there will be places where more workers will be found than required. Concerning the expected supply of workers, it is also estimated that by 2020 there are key occupations with surpluses, as shown in Table 5.

Table 5

Key occupations with surpluses by 2020

\begin{tabular}{cc}
\hline Occupation & Surpluses [thousands of workers] \\
\hline Electricians and linemen & 3.01 \\
Administration, Marketing and Foreign & 0.34 \\
Trade Assistant & 0.24 \\
Electrical technicians & 0.21 \\
Lawyers & 0.14 \\
Coordinators and area managers in & 3.94 \\
construction, repair and maintenance &
\end{tabular}

The table above shows that the Electricians and Linemen occupation is the one that will have a greater surplus in 2020. That an occupation has a surplus means that the workers will exceed the demand of the sector, either because the occupation does not suffer shortage or difficulty to be found, or due to the rapid increase in energy generation projects and the high number of graduates capable of working in the energy sector, especially in the State of Mexico and Mexico City.

On the other hand, it is also estimated that there will be gaps in skills and occupations of workers in the energy sector because a high level of specialization is required. The key occupations with the largest gaps are shown in Table 6.

Table 6

Key occupations with larger gaps by 2020

\begin{tabular}{cc}
\hline Occupation & Gap [thousands of workers] \\
\hline Directors and managers in generation and & 1.53 \\
provision of electricity and water & 1.15 \\
Civil and construction engineers & 0.51 \\
Electrical engineers & 0.44 \\
Mechanical engineers & \\
Mechanics and technicians in the & 0.30 \\
maintenance and repair of mechanical & \\
equipment, motor vehicles and industrial & 3.93 \\
instruments &
\end{tabular}

Source: Own elaboration (SENER, 2016b).

In the previous table, the greatest gaps will be found in the occupations of directors and managers in the generation and provision of electricity and water and civil and construction engineers.

\section{Methodology}

Due to the effects of climate change caused mainly by GHG emissions, it was necessary to identify the sectors with the highest contribution to pollution in Mexico, consulted in the First Biennial Update Report to the United Nations Framework Convention on Climate Change Ministry of Environment and Natural Resources and the National Institute of Ecology and Climate Change. This identification served to establish which are the sectors 
where it would be appropriate to make a restructuring that allows the country's transition to clean energy. On the other hand, it was pertinent to recognize which area of the energy sector produces more GHG emissions.

From the report of the National Institute of Statistics and Geography on occupation and employment, during the fourth quarter of 2017, the figures for workers by sector of activity in Mexico were obtained. With this information, it was possible to visualize which jobs and what areas can be transformed, or where the training of workers would be viable. Next, the most relevant occupations in the development of clean energies were determined, with the support of the Energy Sector Talent Perspective Report of the Ministry of Energy. Based on this, the vulnerable areas and the new areas of opportunities regarding the energy labour market could be observed.

\section{Results}

\subsection{The solar industry: A developing labour market}

According to the Strategic Program of Training of Human Resources in Energy Matters, to meet the demand of the sector, Mexico needs to train a minimum of 135,000 high-level experts, professionals and technicians in different specialties between 2015 and 2018 - $80 \%$ corresponding to personnel with a technical profile or vocational careers and $20 \%$ of the upper and postgraduate level-, as well as developing mechanisms and strategies that allow the supply and demand of human resources to be properly connected (SENER, 2017).

The environmental, social and economic impacts are focused on the integration between solar energy systems and the surrounding environment to assess the impact of each study. Economic impacts are assessed by creating new business opportunities and building new housing units. The analysis of social impacts considers interaction with the community and users as part of the planning process (Lobaccaro et al., 2019).

It is estimated that the sector will register investments for 50,000 billion dollars between 2015 and 2018 and for every million dollars invested 2.7 direct jobs are generated, on average, and for every direct job generated, 2.7 indirect jobs are opened (SENER, 2017).

In Table 4 we could see some of the occupations that will be required in the clean energy sector and then a table with the human resources required for the Solar Industry in Mexico (ISM) is presented, as well as the skills and type of specialization that must comply; It includes professionals dedicated to the research of materials, parts and systems, and the evaluation of resources, as well as those who are dedicated to the design, installation, sale, operation and maintenance of the systems and their components (SENER, 2017).

An example of how many jobs can be generated in the solar energy sector, helping to mitigate poverty in Mexico, reducing GHG emissions and developing the energy sector with a sustainable approach, is shown in Table 7. To this we must add that global employment in the electricity sector would increase from 21 million in 2015 to 35 million in 2050, and renewable energies are expected to represent $80 \%$ of total direct energy jobs by 2050 as well as jobs of operation and maintenance, which will contribute $50 \%$ of the total for the same year (Ram, Aghahosseini \& Breyer, 2020). 
Table 7

Human Resources required for the Solar Industry in Mexico

\begin{tabular}{ll}
\hline Stage & Skills \\
\hline $\begin{array}{l}\text { Equipment, } \\
\text { manufacturing and } \\
\text { distribution }\end{array}$ & $\begin{array}{l}\text { The human resources for this stage must have } \\
\text { theoretical and practical knowledge of solar energy. } \\
\text { The profiles focused on this stage must have great } \\
\text { knowledge in logistics, manufacturing and quality } \\
\text { control. While the marketing and sales staff must be } \\
\text { skilled in their tasks because they are innovative } \\
\text { technologies entering the market. }\end{array}$
\end{tabular}

Occupation

Technicians and laboratory assistants.

Systems or computer science engineers.

Manufacturing Engineers

Engineers specialized in construction systems.

Experts in quality control and manufacturing

(industrial, process engineers, etc.).

Industrial engineers specialized in logistics.

Equipment transporters.

Marketers

Sales staff.

\begin{tabular}{ll}
\hline Project & At this stage, it is necessary to have skills in analysis \\
development & and monitoring of production operations, systems \\
& evaluation and identification of needs and obstacles \\
& in the solar industry, whose knowledge facilitates \\
& the development of projects with a sustainable \\
& approach.
\end{tabular}

Architects (small scale projects).

Atmospheric scientists and meteorologists.

Engineers specialized in the evaluation of resources and sites.

Lawyers

Development and land use consultants (environmental or project development engineers). International Relations

\begin{tabular}{|c|c|}
\hline $\begin{array}{l}\text { Construction and } \\
\text { Installation }\end{array}$ & $\begin{array}{l}\text { The human resources necessary for this stage } \\
\text { should preferably have certifications that prove } \\
\text { their knowledge of solar energy. } \\
\text { In the case of installers, it is necessary that they are } \\
\text { properly trained and that they have physical } \\
\text { dexterity and ability to work at heights, } \\
\text { construction and installation of systems, basic } \\
\text { procedures for photovoltaic and photothermal } \\
\text { installations, as well as with certifications to work in } \\
\text { this sector performing facilities in accordance with } \\
\text { the corresponding codes and standards. }\end{array}$ \\
\hline
\end{tabular}

System designers (mechanical, electronic engineers, structural, electrical or renewable energy engineers). Specialized plumbers

Electricians specialized in solar energy.

Specialists in structures.

Installers

Solar concentration

Welders

Project managers (industrial, financial engineers, administrators, among others).

Technicians specialized in photovoltaic installations.

Systems Engineers

Engineers specializing in quality control.

Carriers.

\begin{tabular}{lll}
\hline $\begin{array}{l}\text { Operation } \\
\text { maintenance }\end{array}$ & and & At this stage, skills and technical competencies \\
& similar to those of the previous stage are necessary. Plumbers specialized in solar thermal systems. \\
In general, maintenance for small installations is Specialists in the maintenance of thermo-solar \\
only necessary when a problem occurs in the concentration equipment. \\
installation. In contrast, for large-scale installations, Specialists in recycling and disposal of solid waste \\
the skills demanded at this stage vary according to (environmental engineers, for example). \\
solar technology and are equivalent to that of \\
construction and installation.
\end{tabular}

Source: Own elaboration (SENER, 2017) 


\subsection{The circular economy of Photovoltaic Panels (PV)}

In addition to generating jobs in the energy sector, managers and workers should be concerned about making a circular economy in terms of the administration and management of waste from the main technology that will be used in the solar industry: photovoltaic panels. So that good management of the PV can be carried out, the main materials used for its manufacture, are presented in Table 8 as well as the different types of PV that exist according to their technology.

Table 8

Market share of photovoltaic panels

by technology groups (2014-2030)

\begin{tabular}{|c|c|c|c|c|}
\hline Technology & & 2014 & 2020 & 2030 \\
\hline \multirow{4}{*}{ Silicon-based (c-Si) } & Monocrystalline & \multirow{4}{*}{$92 \%$} & \multirow{4}{*}{$73.3 \%$} & \multirow{4}{*}{$44.8 \%$} \\
\hline & Poly- or multicrystalline & & & \\
\hline & Ribbon & & & \\
\hline & a-Si (amorph/micromorph) & & & \\
\hline \multirow[t]{4}{*}{ Thin film-based } & Copper indium gallium (di)selenide (CIGS) & $2 \%$ & $5.2 \%$ & $6.4 \%$ \\
\hline & Cadmium telluride (CdTe) & $5 \%$ & $5.2 \%$ & $4.7 \%$ \\
\hline & Concentrating solar PV (CPV) & \multirow{4}{*}{$1 \%$} & $1.2 \%$ & $0.6 \%$ \\
\hline & Organic PV/dye-sensitised cells (OPV) & & $5.8 \%$ & $8.7 \%$ \\
\hline \multirow[t]{2}{*}{ Other } & Crystalline silicon (advanced c-Si) & & $8.7 \%$ & $25.6 \%$ \\
\hline & $\begin{array}{l}\text { CIGS alternatives, heavy metals } \\
\text { (e.g. perovskite), advanced III-V }\end{array}$ & & $0.6 \%$ & $9.3 \%$ \\
\hline
\end{tabular}

Source: (Weckend, Wade \& Heath, 2016a; 2016b).

Since mainly Silicon-based PV panels (c-Si) and thin film-based panels (CIGS and CdTe) are used, we will review their components throughout their construction process to determine where we can apply the well-known principle of 3Rs waste reduction: Reduce, Reuse, Recycle (Weckend, Wade \& Heath, 2016a), exemplified in Figure 7.

Figure 7

Process flow diagram of the life cycle stages of photovoltaic panels and the resulting opportunities to reduce, reuse or recycle

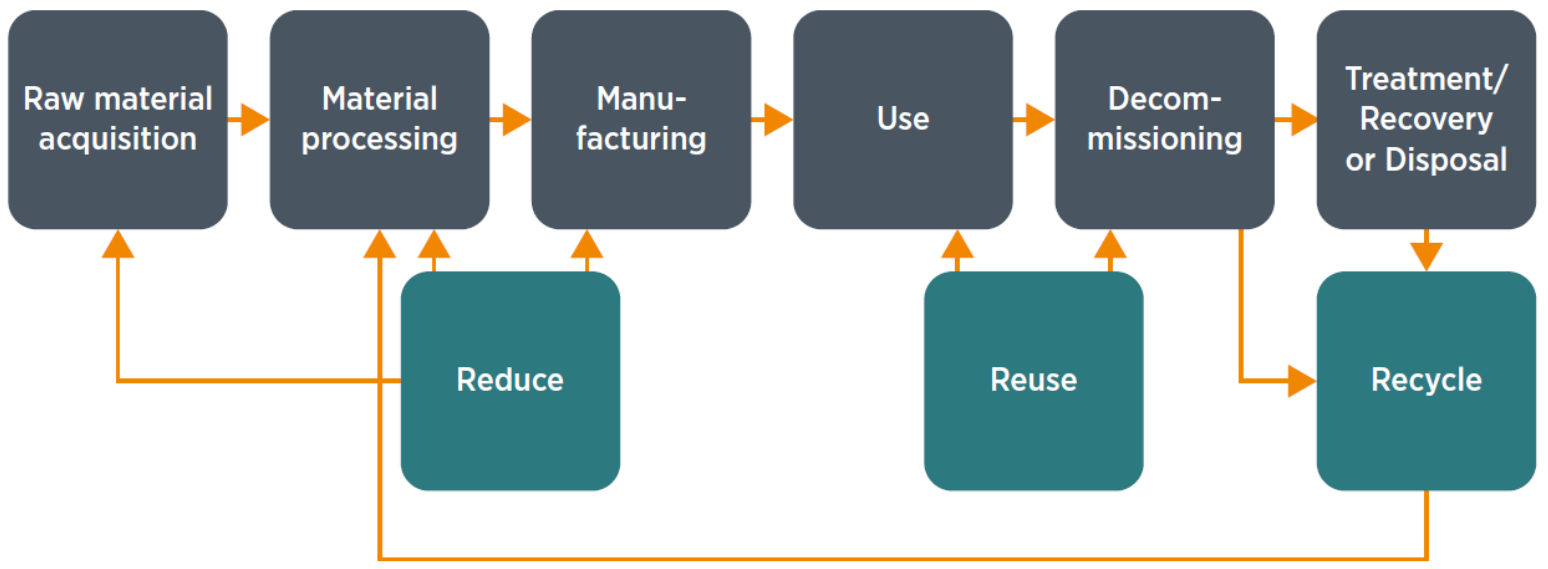

The strong growth of the market, the shortage of raw materials and the downward pressure on the prices of PV panels are driving more efficient mass production, with less use of materials, substitutions of materials and new technologies of greater efficiency. The reuse option follows the reduction option. This covers different modes of repair and reuse. Recycling is the least preferred option (apart from disposal) and is only carried out after the 
first two options have been exhausted. This option provides the processing and treatment of PV panels and can unlock raw materials for the manufacture of new photovoltaic panels or other products.

\subsection{Material savings in photovoltaic panels through R\&D (reduce)}

The efficiency of resources or materials means using the world's limited resources sustainably and minimizing impacts on the environment. The efficiency of resources/materials allows the creation of more value (for example, products) with fewer inputs (for example, resources or materials). The R\&D of PV panels has specifically established priority issues for the reduction of the use of materials or the replacement of different components commonly used in current PV panels:

- C-Si panels: glass, polymer, silicon, aluminium, silver, lead and others.

- CIGS panels: glass, polymer, aluminium, cadmium, gallium, indium, selenium and others.

- CdTe panels: glass, polymer, cadmium tellurium, nickel and others.

Also, much of the R\&D focus on new materials and replacements for these, for example:

Indium: The new transparent layers of conductive oxide incorporate more abundant and cheaper compounds, such as fluorine-doped tin oxide and these can replace indium and tin oxide as frontal electrodes. This reduces the use of indium in the indium-tin-oxide available in some thin-film photovoltaic technologies.

- Glass: A greater optimization for the use of glass is the thickness, the anti-reflective coating and the surface structures, which will increase the transmission of the front glass panels by another $2 \%$ by 2024 .

- Polymers: Encapsulants and backsheet foils are not recycled today because the hard plastic materials that dominate the market cannot be dissolved or melted for recycling without decomposition. Research is looking at reducing or replacing the number of polymers, especially for backsheets that use a polyethene terephthalate foil.

- Silicon: Thinner cells can reduce the amount of silicon used in c-Si cells. For example, by moving on to a subsequent contact cell design, the use of silicon could be reduced by half and energy consumption could be reduced by approximately $30 \%$ (Raithel, 2014).

- Silver: This element is by far the most expensive per unit mass of the c-Si panels, so a significant reduction in silver in the cells is expected for 2018, according to the International Technology Roadmap for Photovoltaic (ITRPV) study (Raithel, 2014) due to recent progress in inkjet and screen-printing technologies.

The next section analyses the different end-of-life options for photovoltaic panels. The environmentally preferable approach is to repair a possible end-of-life panel and adapt it for reuse (Weckend et al., 2016b).

\subsubsection{Repair of PV panels (reuse)}

If defects are discovered during the first phase of the life of a PV panel, customers may try to claim, repair or replacement by use of their warranties. To recover some value of a panel returned through resale, quality tests must be carried out that primarily verify electrical safety and output power. When repairs are necessary and feasible, they generally involve the application of a new frame, a new junction box, diode replacement, new plugs, sockets and more. Solar cells can even be replaced, and panels are laminated. Consequently, the product receives a new label with new guarantees.

Repaired PV panels can be resold as replacements. Alternatively, they can be resold as used panels at a reduced market price of approximately $70 \%$ of the original sale price compared to the new panels.

According to Weibull statistics applied to the forecast of PV panels, a proportion of installed panels can remain intact even after an average useful life of 30 years. If a photovoltaic system is disassembled after its nominal service life, these panels can be reused after quality control and renovation. 
This creates a good opportunity for a significant secondary market of used panels and new repair service jobs in the future. Panels that cannot be repaired or reused will be disassembled and then sent to local waste treatment companies for further processing following local regulations (Weckend et al., 2016b).

\subsubsection{Dismantling and treatment of photovoltaic panels (recycle)}

Since there are currently only moderate quantities of photovoltaic waste in the global waste market, there are not enough quantities or economic incentives to create dedicated photovoltaic panel recycling plants. Photovoltaic panels at the end of their useful life are generally processed in existing general recycling plants.

The following points are important to design any future photovoltaic panel waste recycling system with the best possible results, including high recovery rates and high quality even for materials present in low quantities, regardless of the photovoltaic technology used:

1. Avoid major damage to the PV panel during the dismantling, collection and transport phases.

2. Depending on the economic viability, recover as many valuable materials as possible (for example, silver, copper, silicon, glass, aluminium), scarce (for example, indium, tellurium) and hazardous materials (for example, cadmium, lead, selenium).

3. Use durable labels to help identify the product.

4. Link the material compositions relevant to the recycling and recovery processes to the label.

5. Create panel designs that are recycling friendly.

The main components of the c-Si panels, including glass, aluminium and copper, can be recovered with cumulative yields greater than $85 \%$ by mass of the panel through a purely mechanical separation. And in the case of thin-film panels, large-scale recycling is still in its early stages and will improve as waste volumes and corresponding knowledge about waste treatment increase. Thin-film panels are currently processed and recycled using a combination of mechanical and chemical treatments, a process that can achieve approximately $90 \%$ recovery of glass and approximately $95 \%$ of mass semiconductor material is currently being followed (Weckend et al., 2016b).

\section{Conclusions}

It is expected that in the coming years the production of clean energy will continue to grow, however, it has been observed that the supply and demand of work in the energy sector is not consistent, as they exist and, according to estimates, will continue to exist, surpluses and gaps of important skills in the energy labour market, due either to the lack of specialization of the workers or the location of the available labour supply and the required location of the labour demand do not coincide.

To face up to the first problem, educational institutions could be encouraged to focus more on the sustainable energy sector so that students reach a higher academic level and a specialization in issues related to clean energy. On the other hand, it will also be important to motivate the population that is already working to take training and attend certification programs within the energy sector that, in addition, contribute to specialize them in areas where there are skills gaps and therefore the workforce It is not enough, that is, in the field of sustainable energy.

To address the second problem, incentives could be provided for workers to relocate in areas where the workforce will be required, in addition to providing well-paid jobs and a good standard of living in the location where workers would move.

In the renewable energy industry in Mexico, there is a great opportunity for investment possibilities and continuous improvement. Besides, if the importance of the circular economy is added, we can see that there is 
a large gap in the generation of jobs and the reduction of pollutants, this is an added value that would be given to the renewable energy economy.

As for the solar industry, it can be seen that there is a great opportunity gap in the energy sector in Mexico to generate renewable energies that help the environment, with this being able to generate a labour market with the participation of all kinds of specialists in the sector, from engineers to educators, all with knowledge about solar energy and all that it entails, increasing the employment rate in the country and reducing poverty.

\section{Bibliographic references}

International Renewable Energy Agency (IRENA). (2015). Renewable Energy and Jobs, Annual Review 2015. Abu Dhabi.

International Renewable Energy Agency (IRENA). (2017). Renewable Energy and Jobs, Annual Review 2017. Abu Dhabi.

Lobaccaro, G., Croce, S., Lindkvist, C., Probst, MM, Scognamiglio, A., Dahlberg, J., \& Wall, M. (2019). A multicountry perspective on solar energy in urban planning: lessons learned from international case studies. Revisiones de energías renovables y sostenibles, 108, 209-237.

Merino, L. (2012). The renewable energies. Spain: foundation of the energy of the community of Madrid.

Moon, I. B. (1981). Let the Sunshine in: Free and Inexpensive Materials on Solar Energy. Collection Building.

National Institute of Ecology and Climate Change and Secretariat of Environment and Natural Resources (INECC-SEMARNAT). (2015). First Biennial Update Report to the United Nations Framework Convention on Climate Change. Mexico.

National Institute of Statistics and Geography Mexico (INEGI). (2018). Results of the national occupation and employment survey figures during the fourth quarter of 2017.

Raithel, S. (2014). International Technology Roadmap for Photovoltaic (ITRPV.net) Results 2013.

Ram, M., Aghahosseini, A. \& Breyer, C. (2020). Job creation during the global energy transition towards $100 \%$ renewable power system by 2050. Renewable Energy, 16(7), 4667-4674.

Renewable Energy Policy Network for the 21st Century (REN21). (2016). Renewable Energies 2016, World Situation Report. Spain.

Sardon, J. M. (2003). Renewable energies for development. Editorial Paraninfo.

Secretary of Government (SEGOB). (2013). National Development Plan 2013-2018. Mexico.

Secretary of Energy (SENER). (2016a). Prospective of Renewable Energies 2016 - 2030. Mexico.

Secretary of Energy (SENER). (2016b). Talent prospect of the energy sector, volume 6: analysis of talent gaps in the energy sustainability subsector. Mexico.

Secretary of Energy (SENER). (2017). ProMéxico, The photovoltaic and photothermal solar industry in Mexico. Mexico.

Secretary of Energy (SENER). (2017a). National Energy Balance 2016. Ministry of Energy. Mexico.

Secretary of Energy (SENER). (2017b). National Electric System Development Program 2017 - 2031. Mexico. 
Weckend, S., Wade, A., \& Heath, G. (2016a). End of Life Solar PV Panels, 2016. International Renewable Energy Agency, 37-57.

Weckend, S., Wade, A., \& Heath, G. (2016b). End of Life Solar PV Panels, 2016. International Renewable Energy Agency, 75-89.

\author{
Esta obra está bajo una Licencia Creative Commons \\ Attribución-NoCommercial 4.0 International \\ (cc) BY-NC
}

